\title{
ZMĚNA ZÁKONA O ČESKÉ NÁRODNÍ BANCE JAKO CESTA K MĚNOVÉMU FINANCOVÁNÍ?
}

\author{
MICHAEL KOHAJDA
}

\begin{abstract}
Amendment to the Act on the Czech National Bank as an Opportunity for Monetary Financing?

In his article, the author deals with the amendment to the Act on the Czech National Bank adopted in the spring of 2020 . He examines the process of adopting this amendment and also the reasons for its adoption from the point of view of monetary financing. He examines whether the consequence of this amendment potentially could not result in enabling monetary financing by the Czech central bank. Furthermore, his article also deals with the nature and risks of monetary financing, discusses the difference between direct and indirect monetary financing, the reasons for the ban on monetary financing and the importance of whether monetary financing is carried out directly or indirectly from the perspective of this ban and its reasons. In conclusion, the author evaluates the adopted amendment to the Act that this amendment introduces instruments that could be used for monetary financing, but that the specific use of the instruments is more important, as they can be used for monetary policy purposes or to maintain financial stability, where their use is generally acceptable, but also for the monetary financing, where their use should be prohibited.
\end{abstract}

Keywords: central bank; Czech National Bank; monetary financing; monetary law; monetary policy instruments

Klíčová slova: centrální banka; Česká národní banka; měnové financování; měnové právo; měnověpolitické nástroje

DOI: $10.14712 / 23366478.2020 .24$

\section{1. ÚVOD}

Česká národní banka je stejně jako standardní moderní centrální banky ekonomicky rozvinutých států nadána poměrně širokou mírou své nezávislosti na jiných státních mocích. Členit jednotlivé druhy nezávislosti centrální banky je možné na nezávislost institucionální, funkční, personální, finanční a rozpočtovou. ${ }^{1}$ Lze shrnout, že Česká národní banka byla nadána nezávislostí v poměrně širokém rozsahu, a to právě i v porovnání s centrálními bankami jiných ekonomicky rozvinutých států. Nejen že v právní úpravě centrálního bankovnictví v České republice byly respektovány požadavky unijního práva na nezávislost centrální banky členského státu, ale i ve spojitosti s autoritativním soudním výkladem této české právní úpravy Ústavním soudem je možné rozsah, míru nezávislosti České národní banky hodnotit jako nadstandardně vysokou.

1 Srovnej např́iklad: KOHAJDA, M. Teoretické aspekty postavení České národní banky po 1. dubnu 2006. In: BEDNǍR, V. (ed.). Naděje právní vědy: Býkov 2006. Plzeň: Vydavatelství a nakladatelství Aleš Čeněk, 2006, s. 279-288. 
V březnu 2020 se v údajné souvislosti s pandemií koronaviru COVID-19 objevily úvahy, které následně velmi rychle i prošly legislativním procesem a staly se součástí právního řádu České republiky a které vzbuzovaly otázky vztahující se možné souvislosti s finanční nezávislostí české centrální banky, konkrétně pak k porušení zákazu měnového financování veřejných rozpočtů, zejména toho státního.

Předmětem tohoto článku je úvaha o důvodnosti takovýchto otázek, resp. obav. Těmto obavám samozřejmě může nahrávat také relativní překvapivost vzniku myšlenek vztahujících se k této legislativní změně a rychlost jejich provedení do účinné součásti právního řádu České republiky. Součástí této úvahy pak nutně bude vztah současného unijního i českého legislativního zakotvení finanční nezávislosti centrální banky k finančněprávní teorii vymezující nezávislost centrálních bank, následně pak míra realizace obecných požadavků na finanční nezávislost v podobě českého národního práva. ${ }^{2}$

\section{OTEVŘENÍ CESTY K MĚNOVÉMU FINANCOVÁNÍ?}

Obecně je možné konstatovat, že návrh na změnu oprávnění k obchodování s investičními nástroji České národní banky s protistranami různého druhu není novinkou poslední doby, relativně rozsáhlý návrh novely zákona o České národní bance obsahující i změnu těchto oprávnění obsahuje sněmovní tisk č. $532^{3}$ předložený do Poslanecké sněmovny v červnu 2019, nicméně i tento ve skutečnosti odpovídá již dříve předloženému návrhu změny zákona, který Poslanecká sněmovna ve svém 7 . období nestihla projednat.

Tento původní návrh se stal inspirací pro vládní návrh předložený do Poslanecké sněmovny v březnu 2020 jako sněmovní tisk č. 791, ${ }^{4}$ který se však omezil právě jen na změnu oprávnění k obchodům s investičními nástroji mezi Českou národní bankou a jejími protistranami. Je otázkou, z jakého důvodu byl tento návrh do legislativního procesu předložen. Důvodová zpráva k tomu uvádí: „Důvodem k předložení návrhu zákona je reakce na situaci vyvolanou pandemií nemoci COVID-19, s očekávanými dopady do hospodářství, vč. finančních trhů, přičemž navržené změny jsou v souladu se změnami v provádění měnové politiky v celosvětovém měřítku a zejména v EU, resp. v eurozóně, k nimž došlo od vypuknutí globální finanční a ekonomické krize. V situaci vyvolané pandemií nemoci COVID-19 je stávající znění zákona o ČNB v oblasti obchodů České národní banky (dále jen ,ČNB“) na volném trhu př́liš̌ restriktivní.“5 I další důvody uvedené v této zprávě směřuí k tomu, že po poslední finanční krizi (tedy finanční krizi, která nastala po pádu americké banky Lehman Brothers v roce 2008) se

2 Tento text byl zpracován v rámci programu „PROGRES Q02 - Publicizace práva v evropském a mezinárodním srovnání” realizovaného v roce 2020 na Právnické fakultě Univerzity Karlovy.

3 Sněmovní tisk č. 532 v 8 . období Poslanecké sněmovny PČR. Dostupný z: https://www.psp.cz/sqw/historie .sqw? $=532 \& \mathrm{O}=8$ [cit. 2020-05-07].

4 Sněmovní tisk č. 791 v 8. období Poslanecké sněmovny PČR. Dostupný z: https://www.psp.cz/sqw/historie .sqw?o=8\&T=791 [cit. 2020-07-05].

5 Důvodová zpráva k návrhu zákona, kterým se mění zákon č. 6/1993 Sb., o České národní bance, ve znění pozdějších předpisů, str. 3. Dostupná z: https://www.psp.cz/sqw/text/tiskt.sqw?O=8\&CT=791\&CT1=0 [cit. 2020-07-05]. 
světovým centrálním bankám postupně rozrostl okruh instrumentů, které v rámci svých úkolů mohou používat, nicméně česká právní úprava dosud na tento vývoj nereagovala a ponechala nástroje České národní banky v původní, tradiční podobě. Souvisejícím argumentem je také rozšîrení úkolů, kterých má Česká národní banka dosahovat, které nespočívají jen v péči o měnovou politiku, ale v mnohem širší péči o stabilitu finančního systému. ${ }^{6} \mathrm{~K}$ zajištění naplňování těchto cílů pak Česká národní banka požadovala rozšîrené pravomocí, jak je obsaženo právě ve sněmovním tisku č. 532.

Je však otázkou, nakolik tyto argumenty plně odpovídají účelu, pro který byl vytvořen legislativní návrh obsažený ve sněmovním tisku č. 791 z března 2020, které směřují jen k rozšr̂r̃ení okruhu druhů finančních nástrojů a protistran u obchodů, k jejich provádění měla podle návrhu být Česká národní banka po změně zákona oprávněna.

Odpovědi na tyto otázky je možné hledat ve vyjádření odpovědného představitele exekutivy pro média, konkrétně pak ministryně financí Aleny Schillerové. Ta poprvé oznámila urgentní přípravu této legislativní změny v pořadu České televize Události, komentáře dne 23. března 2020, když uvedla: „Ano, ano. Já jsem se na tom dnes domluvila s panem guvernérem. On se se mnou spojil telefonicky. Hned jsme připravili novelu zákona o České národní bance, zítra to dávám na vládu, bude mimořádná vláda v 9:30 a projednáme tento bod a požádala jsem předsedu Poslanecké sněmovny, aby ho projednal zítra na grémiu tak, abychom mohli tuto novelu ve stavu legislativní nouze projednat. A na základě této novely by Česká národní banka kupovala dluhopisy, kupovala státní dluh od bank. "7 Z tohoto vyjádření je patrný odlišný primární důvod přípravy této legislativní změny, který spočíval v plánu na odkup státního dluhu Českou národní bankou. Tedy v plánu na jistý způsob měnového financování za podmínek blíže specifikovaných v připravené novele zákona o České národní bance.

Vládní návrh novely zákona o České národní bance obsažený ve sněmovním tisku č. 791/0 ve stručnosti obsahoval tyto zásadnější změny:

(a) Oprávnění České národní banky u obchodů prováděných s protistranami určovat druhy těchto obchodů a protistrany v nich. Centrální banka o těchto parametrech rozhoduje autonomně, návrh novely zákona obsahuje jen limit, že tyto obchody musejí směřovat k plnění úkolů České národní banky.

(b) Ruší se omezení okruhu instrumentů, které mohou být předmětem obchodů České národní banky (nástroje peněžního trhu, tj. se splatností do 1 roku) a omezení splatnosti prováděných obchodů na nejvýše 3 měsíce. (Resp. též zlato a devizové peněžní hodnoty.)

(c) Ruší se omezení protistran těchto obchodů (tj. omezení na banky, pobočky zahraničních bank a spořitelní a úvěrní družstva), fakticky je okruh protistran rozšîren na všechny finanční instituce, resp. subjekty obchodující na finančních trzích.

6 K pojmu finanční systém a stabilita finančního systému srovnej například: KOHAJDA, M. Financial system as new theoretical and legislative term. In: HULKÓ, G. - VYBÍRAL, R. (eds.). European Financial Law in Times of Crisis of the European Union. Budapešt': Dialóg Campus, 2019, s. 222-233.

7 Autorův přepis vystoupení A. Schillerové v pořadu Události, komentáře, dne 23. 03. 2020. Dostupné na: https://www.ceskatelevize.cz/porady/1096898594-udalosti-komentare/220411000370323/video/758151 [cit. 2020-07-07]. 
Je vhodné zdůraznit, že návrh novely zákona se nijak nedotkl stávajícího znění ustanovení § 34a obsahujícího zákaz přímého měnového financování v podobě zákazu poskytovat možnost přečerpání zůstatku bankovních účtů nebo jakýkoliv jiný typ úvěru veřejnoprávním subjektům nebo přímý nákup jejich dluhových nástrojů (podrobněji viz níže).

\section{ARGUMENTY V ROZPRAVĚ V POSLANECKÉ SNĚMOVNĚ}

Mezi předložením vládního návrhu a prvním projednání návrhu zákona ve stavu legislativní nouze byl tento návrh velmi diskutován. A to jak na poli legislativního orgánu (zejména na rozpočtovém výboru Sněmovny, při online video hovorech mezi poslanci, zástupci předkladatele a zástupci České národní banky), tak v mediálním prostoru. Tyto debaty byly způsobeny právě prvotním neformálním, mediálním zdůvodňováním nutnosti přijmout okamžitou změnu zákona o České národní bance odkazem na fiskální potřeby státu spojené s probíhající pandemií nemoci COVID-19; sekundárně pak také navrhovanou šr̂rí možných předmětů a neomezením okruhu protistran obchodů České národní banky.

Ze zásadnějších argumentů, které v průběhu rozpravy nad návrhem novely zákona o České národní bance v Poslanecké sněmovně zazněly, je vhodné uvést následující, které shrnují základní důvody pro přijetí návrhu, ale také obavy členů legislativního sboru s přijetím návrhu související.

Poslanec Jiří Dolejš za rozpočtový výbor shrnul cíl nové právní úpravy mimo jiné i následovně: „,̌Reknu to zhruba tak, že všichni přijali myšlenku, že pokud vláda potřebuje rozširríit svůj fiskální prostor (nesroz.) ve svém emisním plánu, musí pokrýt problematiku poměrně značného objemu vládních dluhopisů, tak bude dobré i z hlediska ceny těch dluhopisů, z hlediska toho, že bude dobré, když ty peníze budou co nejlevnější, aby v zádech této transakce stála právě Česká národní banka." 8

Obdobný důvod uvedl také poslanec Jan Hrnčîr: „Uvědomujeme si i to, že vláda si musí půjčovat na opatření spojená s ekonomickou krizí, kterou koronavirus vyvolává, takže s tím, že Česká národní banka bude mít rozšîrené možnosti, tak samozřejmě se výrazně zlevní peníze pro český stát, protože signál investorům bude naprosto jasný, že Česká národní banka se prostě může na sekundárním trhu zúčastnit těch nákupů, takže ta cena potom jde dolů a ušetříme samozřejmě my všichni daňoví poplatníci““9

Poslanec Dolejš nicméně také upozornil na rizika spojená s možností obchodovat na finančních trzích s investičními nástroji bez omezení jejich druhu: „Snad poslední věc, kterou v této věci má smysl říci, je, že velmi důležitým parametrem tedy je, do jaké míry, pokud to rozššrííme i na ty další nástroje, se z České národní banky stane jakási popelnice na méně validní, neřkuli, nechci říct přímo toxická aktiva, protože pochopitelně ti, kteří budou mít ambici prodávat své cenné papíry tímto zpo̊sobem, aby získali likviditu, tak pochopitelně ta kvalita těch aktiv může býti různá.“10

\footnotetext{
8 Dostupné na: https://www.psp.cz/eknih/2017ps/stenprot/044schuz/s044038.htm [cit. 2020-07-07].

9 Dostupné na: https://www.psp.cz/eknih/2017ps/stenprot/044schuz/s044043.htm [cit. 2020-07-07].

10 Dostupné na: https://www.psp.cz/eknih/2017ps/stenprot/044schuz/s044038.htm [cit. 2020-07-07].
} 
Poslanec Miroslav Kalousek k požadavku České národní banky na neomezování druhu investičních nástrojů, které by mohla banka nakupovat, uvedl: „Nepřesvědčila nás argumentace zástupců České národní banky, která ř́kala: „Prosím vás, my nikdy žádné korporátní dluhopisy nakupovat nebudeme. 'A my jsme říkali: ,Ale proč to tedy v tom zákoně chcete mít?‘ A oni říkali: ,Kdyby se to na tom trhu náhodou vyboulilo, abychom to tam měli jako pojistku."“11

Důležité je uvést také vyjádření guvernéra České národní banky Jiřího Rusnoka, k základní otázce vztahu navrhované novely k zákazu měnového financování a k vlivu na státní dluh, který na plénu Poslanecké sněmovny vystoupil jako host: „Chci zdůraznit, že tato novela nijakým zpo̊sobem neprolamuje zákaz měnového financování vlády. Nicméně je pochopitelné, že z hlediska celkových nákladů a financování protikrizových opatření může mít sekundární, terciární pozitivní přínosy i z hlediska celkových nákladů řešení či usměrňování té krize a jejích následků."12 Dále pak guvernér mimo jiné uváděl i prŕíklady jiných rozvinutých států, kde došlo k rozšriření instrumentů, jejichž užití bylo umožněno centrální bankou. Ve vztahu k měnovému financování zazněla z jeho úst také informace: ,„7. dubna centrální banka Nového Zélandu oznámila, že do svého programu nákupu aktiv zahrne i dluhové cenné papíry lokálních samospráv, které nakoupí na sekundárním trhu v objemu až tří miliard novozélandských dolarů během následujících dvanácti měsíců. Podle svého vyjádření totiž v posledních týdnech banka zaznamenala náznaky nedostatku likvidity právě na tomto důležitém trhu."13 Jako argument pro přijetí této novely zazněla z jeho úst tehdy i informace o údajné možnosti nepřímého měnového financování územních rozpočtů na Novém Zélandě.

\section{KOMPLEXNÍ POZMĚŇOVACÍ NÁVRH}

V rámci diskusí mezi vládními stranami, stranami neformálně podporujícími vládu a protivládní opozicí byl připraven komplexní pozměňovací návrh k původnímu vládnímu návrhu novely zákona o České národní bance, který měl znamenat kompromisní řešení, které by umožnilo učinit legislativní změnu požadovanou vládou, ale současně poskytlo opozici jí žádanou jistotu časového omezení rozšřrených pravomocí České národní banky v oblasti obchodů na finančních trzích. Tento pozměňovací návrh načetl poslanec Roman Kubíček a spočíval v doplnění druhého odstavce do stávajícího § 32 zákona o České národní bance, který dosud měl jen jediný odstavec. Znění tohoto navrhovaného druhého odstavce bylo: „Do 31. prosince 2021 je Česká národní banka též oprávněna k plnění svých úkolů obchodovat na finančním trhu s investičními nástroji a dalšími cennými papíry, pohledávkami a dalšími aktivy formou nákupů a prodejů, repo obchodů, vkladů, výpůjček, zápůjček nebo termínovaných obchodů. Ustanovení § 34 a tímto není dotčeno." 14

\footnotetext{
11 Dostupné na: https://www.psp.cz/eknih/2017ps/stenprot/044schuz/s044039.htm [cit. 2020-07-07].

12 Dostupné na: https://www.psp.cz/eknih/2017ps/stenprot/044schuz/s044040.htm [cit. 2020-07-07].

13 Dostupné na: https://www.psp.cz/eknih/2017ps/stenprot/044schuz/s044040.htm [cit. 2020-07-07].

14 Dostupné na: https://www.psp.cz/eknih/2017ps/stenprot/044schuz/s044041.htm [cit. 2020-07-07].
} 
První odstavec $\$ 32$ přitom obsahuje stávající omezení, že Česká národní banka může nakupovat a prodávat jen cenné papíry, a to za účelem usměrnění peněžního trhu. Nový, druhý odstavec pak tato oprávnění rozšiřuje na obchody obecně s investičními nástroji i jinými aktivy a na různorodější formy obchodů s nimi, a to nejen za účelem usměrnění peněžního trhu, ale k plnění všech úkolů České národní banky, v širokém slova smyslu tedy k zajištění stability finančního systému. Toto rozššřrení pravomocí České národní banky je však výslovně časově limitováno do 31. prosince 2021, tj. cca na 21 měsíců, a výslovně toto ustanovení určuje, že zákaz měnového financování obsažený v § 34a zákona o České národní bance není těmito širšími oprávněními dotčen.

Tento komplexní pozměňovací návrh zcela nahrazující původní vládní návrh byl následně Poslaneckou sněmovnou přijat, vzhledem k širšímu konsensu na jeho znění mezi politickými stranami hladce prošel také Senátem a následně jej podepsal i prezident. Tato novela zákona o České národní bance pak vyšla ve Sbírce zákonů pod č. 192/2020. Senát k tomuto návrh přijal i doprovodné usnesení č. 354,15 kterým požádal Českou národní banku o informování o rozsahu využití oprávnění k obchodování na finančních trzích podle této novely zákona o České národní bance.

\section{MĚNOVÉ FINANCOVÁNÍ A JEHO ZÁKAZ}

Otázka přípustnosti, nebo nepřípustnosti měnového financování souvisí s různým chápáním oddělenosti monetární a fiskální politiky. Přímé měnové financování je jednoznačným pojítkem mezi měnovou a rozpočtovou politikou, u nepřímého financování je otázkou názoru a debaty, zda a v jaké míře k propojení těchto oblastí dochází.

V našem politickém a ekonomickém prostoru je při posuzování stavu propojení měnové a fiskální politiky nutno brát ohled zejména na to, že Evropská unie, a konkrétněji Evropská hospodářská a měnová unie, jejímž významným znakem je jednotná Evropská centrální banka a jednotná monetární politika, formálně stále nemá společnou fiskální politiku, ačkoliv Evropská unie má svůj vlastní rozpočet (a v rámci EMU již i společnou monetární politiku). Je tak evidentní, že společná unijní politika může být naplňována právě a jen politikou měnovou prostřednictvím zemí EMU, která je v rukou unijních orgánů, nikoliv však politikou fiskální. Z tohoto úhlu pohledu je pak vhodné posuzovat nastavení pravidel a také realizaci a dosahování politických cílů v Evropské unii. Odlišný pohled by však měl panovat v případě národního státu, který si dosud zachoval národní centrální banku vykonávající měnovou politiku, jež stojí vedle fiskální politiky určované a vykonávané exekutivou.

Svět ekonomického poznání může jmenovat mnoho historických zkušeností, kdy exekutiva financovala svou politiku díky (následně nenávratnému) převodu peněžních prostř̌edků emitovaných centrální bankou, často skrytých do úvěrů různého druhu, které nebyly splaceny. Nezvratným důsledkem tohoto procesu bylo nerovnovážné navýšení

15 Dostupné na: https://www.senat.cz/xqw/xervlet/pssenat/htmlhled?action=doc\&value=94635 [cit. 2020-07-07]. 
objemu peněz v oběhu bez souvisejícího zvýšení jejich potřeby nebo změny rychlosti cirkulace peněz v oběhu, což nezadržitelně přivodilo velmi vysokou inflaci, hyperinflaci a často úplný kolaps měny. Tyto historické zkušenosti nás varují před měnovým financováním jakéhokoliv druhu, nicméně tyto situace se v průběhu času bohužel opět a opět opakují. Na základě těchto empirických zkušeností obsahuje moderní právní regulace centrálního bankovnictví ekonomicky rozvinutých států obvykle ustanovení měnové financování zakazující. Často je však v takovém ustanovení obsažena limitace jen na přímé měnové financování. Cílem těchto právních zákazů je primárně ochrana cenové nebo měnové stability, sekundárně však také ochrana nezávislého postavení centrální banky vůči moci výkonné. Měnové financování je tak v současné době tabu centrálního bankovnictví, alespoň tedy přímé měnové financování.

Například Smlouva o fungování Evropské unie obsahuje zákaz přímého měnového financování v ustanovení článku 123 odst. 1: „Evropské centrální bance nebo centrálním bankám členských států (dále jen ,národní centrální banky“) se zakazuje poskytovat možnost přečerpání zůstatku bankovních účtů nebo jakýkoli jiný typ úvěru orgánům, institucím nebo jiným subjektům Unie, ústředním vládám, regionálním nebo místním orgánům nebo jiným veřejnoprávním orgánům, jiným veřejnoprávním subjektům nebo veřejným podnikům členských států; rovněž je zakázán přímý nákup jejich dluhových nástrojů Evropskou centrální bankou nebo národními centrálními bankami.“ Textově téměř shodné ustanovení pak obsahuje také § 34a odst. 1 zákona o České národní bance. Nepřímé měnové financování však ani v jednom z těchto pramenů zakázáno není.

Zákaz měnového financování souvisí s neoliberalistickým náhledem na svět, kdy peníze nemají být tvořeny státem nebo centrální bankou pro stát. Peníze mají být primárně tvořeny soukromými bankami, úlohou centrální banky je pak refinancovat komerční banky (nikoliv stát). Postupem doby však v realitě pro komerční banky staly zejména státní dluhopisy vítaným zdrojem výnosů z investic.

Zjednodušeně řečeno měnové financování znamená financování výdajů veřejných rozpočtů penězi centrální banky. Cílem tohoto postupu může být zajištění dostatečných finančních prostředků pro provoz státu, popřípadě v kombinaci s navýšením měnové báze.

Přímé měnové financování může spočívat bud’ v možnosti přečerpat zůstatek bankovního účtu veřejnoprávního subjektu vedeného u centrální banky, nebo v přímém odkupu dluhového nástroje vydaného veřejnoprávním subjektem (zejm. státem nebo místní samosprávou), ale také soukromoprávním subjektem ve veřejných rukou (např. státní investiční banka), centrální bankou od jeho emitenta.

Nepřímé měnové financování spočívá v odkupování dluhu veřejnoprávních subjektů (zejména státu) na finančních trzích od subjektů, které tyto dluhy původně nakoupily na primárním trhu nebo od jiných subjektů na trhu sekundárním. V každém př́ípadě centrální banka opět investuje jí emitované peníze do veřejnoprávního dluhu. Výhodu tohoto postupu lze ( snad důvodně) spatřovat v tom faktu, že finanční instituce na primárním trhu nakoupí veřejnoprávní dluh po zvážení jeho rizikovosti a s vědomím, že takový dluh, pokud by byl př́liš rizikový nebo málo výnosný, následně nebude moci snadno nebo výhodně prodat $\mathrm{v}$ prrípadě potřeby navýšení své likvidity nebo při naplňování 
investiční strategie. Proto by finanční instituce měla nakupovat pouze dluh kvalitní, nikoli příliš rizikový. Zde je možno shledat odlišnost od přímého nákupu veřejnoprávního dluhu centrální bankou, která např́klad kvůli nedostatku nezávislosti může být motivována koupit takový dluh bez ohledu na jeho rizikovost. Limitace jen na nákup veřejnoprávního dluhu na sekundárním, otevřeném trhu tedy může být jistou pojistkou chránící centrální banku od tlaků exekutivy na nákup nekvalitního dluhu.

Faktické důsledky přímého i nepřímého financování jsou však shodné, centrální banka nakoupí veřejnoprávní dluh, zejména v podobě státních dluhopisů, ze svých, jí samotnou emitovaných peněžních prostředků. Dojde tak ke zvýšení měnové báze, otázkou pak zůstává reálnost opačného postupu v budoucnu. Vzhledem k refinancování státních dluhopisů novými státními dluhopisy o tom lze mít oprávněné pochybnosti.

Možným dalším argumentem pro použití těchto instrumentů centrální bankou je naplňování měnověpolitických cílů spočívajících v udržení měnové nebo cenové stability. Je však otázkou, zda v současné době a za současné situace dlouhodobého přebytku likvidity v ekonomice je toto správný nástroj měnové politiky. Lze se domnívat, že při využití tohoto instrumentu centrální bankou veřejnoprávní subjekty získané peníze převedou k domácnostem a firmám, ty je následně utratí a tyto prostředky ve své většině následně skončí jako úložky u komerčních bank, které si je uloží u banky centrální.

Je pak tedy otázkou, jaký skutečný vliv mají tyto rostoucí rezervy na inflaci, pokud je nákup veřejnoprávních dluhopisů činěn s cíli měnověpolitickými. Vzhledem k měnovému financování skrytému pod název kvantitativní uvolňování je zřejmé, že tento postup v dnešní době nemá zásadnější vliv na růst inflace. Spíše je rostoucí likvidita zdrojem munice pro spekulace přesahující racionální podstatu investic. Důvodem rozšriřrení čistých spekulací může být právě skutečnost, že nadbytečná likvidita končí na účtech komerčních bank, nezůstává v reálné ekonomice, nepůsobí jako zdroj větší produkce bohatství - možná právě proto, že je pro reálnou ekonomiku skutečně nadbytečná.

\section{ZÁVĚR}

Cílem toho článku bylo popsat novelu zákona o České národní bance, která prošla na jaře roku 2020 Parlamentem České republiky. Předkládaný úhel pohledu se soustředil na otázku, zda novela umožnila měnové financování, nebo nikoliv. Současně pak také krátce pojednal o měnovém financování a jeho možném významu v současné ekonomické situaci.

Je vhodné nejprve shrnout, že na základě historických zkušeností je nutno se přiklonit k názoru, že měnové financování má být zakázáno. Není správné přitom rozlišovat, zda se jedná o přímé nebo nepřímé měnové financování. I když je možné konstatovat, že nepřímé měnové financování snižuje rizikovost takového nástroje díky obezřetnosti komerčních bank, které při předchozím nákupu veřejného dluhu posuzují jeho kvality, navíc je takto přerušena možná přímá linka mezi exekutivou a centrální bankou. Výsledek přímého i nepřímého financování je totiž stejný; využití centrální bankou úmyslně emitovaných peněz pro financování veřejného dluhu. 
Na druhou stranu je však vhodné zvážit, zda zákaz měnového financování má být vztažen na samotné instrumenty, které centrální banky při měnovém financování používají. Je nutno připustit, že tyto nástroje lze v určitých případech použít i s jiným cílem než pro financování veřejného dluhu. $V$ případě odkupu dluhových nástrojů mohou totiž existovat výjimky, a to $\mathrm{v}$ případě, že jejich přímý odkup je činěn s čistými měnověpolitickými úmysly. Relativně vhodným příkladem tohoto postupu mohou být operace Evropské centrální banky v programu Outright Monetary Transactions (OMT). ${ }^{16}$

Je vhodné tedy hodnotit nikoliv nástroje upravené tou kterou legislativou, ale smysl a důvod jejich zavedení v legislativě. Tytéž nástroje mohou být užity pro měnové financování v jednom případě, nebo pro udržení měnové stability v případě jiném. Proto je vždy nutno hodnotit nejen takový nástroj, ale způsob a okolnosti jeho užití.

Z tohoto úhlu pohledu je pak vhodné hodnotit také novelizaci zákona o České národní bance spočívající v (zatím) dočasné úpravě, rozšǐření okruhu nástrojů, které Česká národní banka může na finančních trzích využít. Hodnocení zde ale musí být velmi obezřetné. Nově zavedené instrumenty centrální bance jistě umožní rozšsiřit její paletu měnověpolitických nástrojů a nástrojů k udržování finanční stability, jak je uváděno i v oficiálním zdůvodnění návrhu novely. Nutno je ale zbystřit v případě prezentovaných důvodů, které urychlenou př́ipravu a přijetí této novely doprovázely. Jak slovní vyjádření ministryně financí, tak zdůvodnění některých vládních a provládních poslanců v Poslanecké sněmovně se jasně vztahovala k financování státního dluhu, ke zlevnění nákladů na státní dluh. $\mathrm{Z}$ tohoto pohledu by se pak jednalo o jednoznačné měnové financování, které je nutno považovat za nepřípustné. V takovém případě ničemu nezabrání ani zákaz přímého měnového financování výslovně obsažený v české i unijní legislativě.

Je tak nutno uzavřít, že nikoliv samo zavedení konkrétního nástroje do zákona o České národní bance (který je v tomto případě možno v novelizovaném ustanovení najít) je způsobem, jak umožnit měnové financování (které má být nepřípustné), ale porušením zákazu měnového financování je až jeho využití k vlastnímu měnovému financování, a to bez ohledu, zda přímou nebo neprrímou cestou.

Doc. JUDr. Michael Kohajda, Ph.D.

Právnická fakulta Univerzity Karlovy

kohajda@prf.cuni.cz

orcid.org/0000-0001-7235-0921

\footnotetext{
16 Srov. TOBER, S. Monetary Financing in the Euro Area: A Free Lunch? Intereconomics. 2015, roč. 50, č. 4, s. 214-220. Dostupný z: https://www.intereconomics.eu/contents/year/2015/number/4/article/monetary -financing-in-the-euro-area-a-free-lunch.html [cit. 2020-07-08]. K vlastní podstatě OMT pak: https://www .ecb.europa.eu/press/pr/date/2012/html/pr120906_1.en.html [cit. 2020-07-08].
} 